Anca CHIOREAN

Faculty of Letters, Babeș-Bolyai University

Cluj-Napoca, Romania

anca_chiorean91@yahoo.com

\title{
THE VERNACULARS OF NO ONE, REALLY. THE (UN?)TRANSLATABLE FICTIONAL LANGUAGES
}

Recommended Citation: Chiorean, Anca. "The Vernaculars of No One, Really. The (Un?)Translatable Fictional Languages". Metacritic Journal for Comparative Studies and Theory 7.2 (2021). Doi: https://doi.org/10.24193/mjcst.2021.12.08

\begin{abstract}
The present paper aims to show the two possible directions, effects, manifestations of the fictional languages in general. Thus, according to the purposes of their creation, fictional languages have, throughout history, been created in order to achieve certain political, aesthetic or playful purposes, but the most fundamental feature that divides them into two categories is one strongly linked to the purpose of their creation: whether or not they can be learned and used in day-to-day life. Thus, whether they originated in the Sci-Fi, Fantasy or in the literary Avant-Garde universes, the issue of their purpose (to hide or to reveal meaning) also raises the issue of their translatability and, most of all, the issue of their "educability", issues that may or may not harm their aesthetic dimensions.
\end{abstract}

Keywords: untranslatable, translatable, fictional languages, aesthetic purpose, transnationalism, translinguialism

Translation has never been a sterile semantic equivalency based on the grammatical laws of the target-language. The "transfer" of meaning is indeed the foundation of the practice, the "creation of equivalencies between texts belonging to different languages"1 (Cornea 214), challenging the linguistic code to adapt through decryption. The

\footnotetext{
1 "realizarea de echivalențe între texte aparținând unor limbi diferite" (my translation).
} 
instrumentation used in the practice of translation is wide and it employs an entire mechanism of interpretation that pendulates between cultures and different fields:

translation understood as a symbolic shift; it recognises the plurality of knowledge by placing it on both sides of the linguistic frontier that separates nations and individuals. (...) Translations basically sets out to integrate the differences in its own cultural context, thus making them intelligible and fertile ${ }^{2}(216)$.

The act of negotiating the meaning between the target cultural sphere and the source cultural sphere thus takes place within both languages. One approach says that

[o]ne sense of the term «translatable», then, is signalled by Derrida's use of the hyperbole, a figure common to geometry and rhetoric. Here, if we are to take the figure seriously, and if we are to hold fast, first, to the geometrical sense of the term, 'to translate' means to map one point or quantum on to another according to an algorithm: translation is understood as mechanics, as a mathematical function, as measure or common measure. This sort of «translation» pertains to natural languages if they can be imagined to be mapped on to a smooth mathematical, or mathematizable, or quantifiable space. Both word-for-word translation and sense-for-sense translation, those archaic Cain-and-Abel brothers of the translational Pantheon, can be imagined according to this sort of mathematical, functional paradigm (Lezra 181).

When the text does not respect the "translation brotherhoods", phenomena connected to the untranslatable appear, such as the translation failure, the over-translation or the under-translation. However, there are also situations in which the untranslatable is a force in itself.

The theories of translation have, throughout the years, explored the depths and effects of the semantic transfers from within the conventional languages, as well as the issues raised by untranslatability.

\footnotetext{
2 "traducerea e înțeleasă ca deplasare simbolică; ea conștientizează pluralitatea cunoașterii, prin aceea că o situează de ambele părți ale frontierei lingvistice, care separă națiunile între ele și indivizii între ei. (...) traducerea își propune, în fond, să integreze diferențele în contextul cultural propriu, făcându-le inteligibile și fecunde" (my translation).
} 
The overlap with other cultural systems can be accomplished through different means, one of which is translation. Undoubtedly, in order to enter a different culture, a «foreign» culture must stop being so... foreign; through the act of translation, it must try to acquire a name and a place within the host culture (Frențiu 50).

I. M. Lotman does assert that we are prisoners of language, that we make great efforts to surpass its limits, that our wrestle with language is as old as language itself and the semiotic space contains untranslatable "black holes" (cf. Lotman 153). However, for the most part, translations studies discuss the difficulties and possible solutions for the cultural blockages created by metaphors, wordplays, phonetic games, more or less subtle nuances, all solvable by negotiating the meaning between the source-language (or the source cultural sphere) and the target-language (or the target cultural sphere), through interpretations, contextualisation, reformulation etc. Such solutions may apply to texts that suffer a "translation resistance" somewhat unintentionally.

Nonetheless, the untranslatability of the texts whose raison d'être lies within themselves is a completely different issue.

The notion of unspeakable/unwriteable semantic representation (or «language speaking to itself») is not alien to translation theory, though. If this could be, nevertheless, touched or described in some objective way, it would not be culturally bound, but probably trans-cultural and, ultimately, a meta-cultural availability to act and react so as to create language and culture, no matter in which order of priority (Tătaru 392).

Fictional languages are not the results of an evolution, as is the case of the natural languages, but they are the results of the intellectual efforts to produce a completely original text, in an isolated moment in history and serving a certain purpose.

\section{Supercalifragilisticexpialidocious}

Theodor Seuss Geisel (Dr. Seuss) is one of the most famous authors of invented words meant to produce certain effects - the Stunt Word, defined as "an informal term for a WORD created and used to produce a special effect or attract attention, as if it were part of the performance of a stunt man or a conjuror" (excerpt from the Concise Oxford 
Companion to the English Language); but perhaps the most famous fictional word of all time was sung by Julie Andrews and Dick Van Dyke in Mary Poppins (1964). Despite it having been assumed as an original creation by the Sherman brothers, it appears to have been used in even older contexts:

In fact, the earliest known written record of a variant is for supercaliflawjalisticexpialidoshus from an «A-muse-ings» column by Helen Herman in The Syracuse Daily Orange (Syracuse University), March 10, 1931. The columnist muses about her made-up word, describing it as including «all words in the category of something wonderful» and «though rather long and tiring before one reaches its conclusion, ... once you arrive at the end, you have said in one word what it would ordinarily take four paragraphs to explain» (excerpt from Merriam-Webster).

Although the wider meaning of the term points to "wonderful", its breakdown (super: above, over, extreme; cali: beauty; fragilistic: delicate; expiali: to atone, to make amends; docious: educable, able to learn) opens two directions of interpretation: "atoning for educability through delicate beauty" and/or "atoning for extreme and delicate beauty while remaining highly educable" (see Urban Dictionary). Therefore: either compensating for educability through aesthetics (for the argument's sake: something that cannot be learned, but it has aesthetic stakes), or something that compensates for the aesthetics, but remains highly educable (something that does not necessarily have aesthetic stakes, but can be learnt).

\section{Atoning for extreme and delicate beauty while remaining highly educable}

In 1880, the German priest Johann Martin Schleyer invented the Volapük language, containing a vocabulary based on English and Romance languages. In spite of its grammatical difficulties, it did gain thousands of followers. However, the most widespread (and the most "educable") invented language is Esperanto, "the vernacular of no one" (Kellman 7), created by Lazarus Ludwig Zamenhof in 1887, under the pseudonym "Doktoro Esperanto" (Doctor Hopeful), in the volume Unua Libro. Its purpose was to facilitate world peace by using a language that could have been common to all: 
Esperanto is the most successful of the artificial, universal languages devised in the late nineteenth century and has the utopian aim of bringing international harmony through a common tongue. The system is based on common words in most tongues that have a basis in Latin grammar. It is easy to learn and master quickly. It was published first in 1887 in that part of Poland under oppressive rule by czarist Russia (...). Over 30,000 items of original or translated literature are in the language as well as some scientific journals. It has over 8 million supporters (Tahair).

Obviously, the political purpose (and the humanitarian one, considering the presence of hope in both the name of the language and in the author's pseudonym) surpasses the aesthetic one, but the applicability of the Esperanto language did not elude the Romanian culture: its representation can be found, for instance, in volumes such as Constantin Dominte's Din lirica de expresie esperanto. 11 traduceri şi adaptări în română (Rotterdam: Eldonejo Bero, 2005) (Poetry in the Esperanto language. 11 translations and adaptations in Romanian), or even Poeziajoj. Eminescu en esperanto / Poezii. Eminescu în Esperanto (Poetry. Eminescu in Esperanto), a bilingual edition issued by Aurora Bute and Eugen Simion in 2005.

Esperanto is part of the system of international auxiliary languages whose purpose is to bring together, or to facilitate the communication between peoples that have nothing in common. The linguistic cosmopolitism is, in this case, understood as the best tool in creating the context for peaceful cohabitation and not to reach new aesthetic levels of literature or to test the limits of language. Moreover, the incipient versions of the invented languages created communities of speakers - communities that even had their own publications. The translation of the fictional languages represents, in this case, the path towards learning and thus towards one's inclusion in a certain transnational community - a trans-anything community, for that matter, considering the force with which the fictional language seems to overcome any form of cultural blockage:

Can the thing that Esperantists share with each other really be called a culture? Professional anthropologists might be insulted by the question. All I know is that if you told me you saw a nudist, a gay ornithologist, a railroad enthusiast, and a punk cannabis 
smoker walking down the street together, I would be waiting for the punch line. But if you then told me they were speaking Esperanto, no punch line would be necessary. It would all make complete and utter sense (Okrent 116).

In the first part of the twentieth century, the "educability" of fictional languages was even upheld at an institutional level, as an alternative means of learning the (general) rules by which a signifier behaves in relation with a signified. A study from 1927, for instance, states that

There is a growing interest among progressive educators in the educational value of teaching an artificial language as a basis for all language study. The unique value seems to lie in the fact that a language artificially constructed puts into practice, through its absolutely regular grammar and word-formation, certain theories of structure which illustrate to the pupil the functions of grammar and word-formation" (Eaton 87).

And uses the example given by the Esperanto language:

The study of an artificial language brings about the improved use and understanding of the mother-tongue as well as enlarging of the vocabulary. A child of ten or so years knows what «word», «hand» and «father» mean. But he very likely will not possess the adjectives «verbal», «manual», «paternal», which have different roots and are less frequently used. In Esperanto, «word» and «verbal» have the same root, one with a substantive ending and one with an adjective ending. The same is true of «hand» and «manual», «father» and «paternal» (89).

The true necessity of translating any fictional language can be brought into question. While Klingon, for example, has a very well-founded linguistic system that can be applied to day to day life and the purpose of its use requires subtitles, the fictional languages of the Romanian literature can function in both forms, but they cannot be applied outside their literary contexts.

There is an immense theoretical potential in what would appear to be the untranslatability of the fictional languages created within the Romanian Avant-Garde literature. The direction of their intentionality may be traced from bilingualism to the 
creation of certain systems of articulation that are truly international, from purely playful attempts of babbling that mean to delight, to the forms of liberating human expression, or to the export of the unreadable by challenging the textures of almostsameness. In exploring the theoretical pillars that sustain the validity of the conceptual stances taken in manifestations such as Geo Bogza's rota dria vau unfamiliarity, the depths of prodigious stuttering, or within the self-referential occurrences of Virgil Teodorescu's Leopard language, the present paper employs different tools in an attempt to follow the ripples of sounds and images through their visual translation, transliteration or basic transfer of meaning from artificial uniqueness to somewhat conventional uniqueness. The primary focus is not on the literary import-export mechanisms and their results, since this issue has already been explored in-depth numerous times. The idea is that, in fact, the issue of untraslatability could be a carrier or a reflector of theory or of certain theoretical stances in the case of fictional languages. However, the idea cannot be applied to all fictional languages, since the functionalities are in question: the fictional languages of the fantasy or SF universes have a completely different functionality, since they gained a cult following and their systems have been adopted as languages that have internally consistent grammatical laws 3 . The functionality basically establishes the difference between translations and subtitles:

Other languages, such as Klingon, were created to provide greater realism in fictional settings. The fact that they might be taken up by fans who learn to speak them fluently and to translate other works into them is entirely incidental. The point is, however exotic the language, the creator had some specific goal in mind when developing the phonology, grammar, and vocabulary. But sometimes languages can be invented for their own sake, purely as an intellectual endeavour (Koenig).

The creative meaning behind invented languages can go two ways:

a) either to emphasise the fact that we are faced with something completely different from anything we know - a people or a species that is different from anything any of us have ever encountered, one aspect of which is reflected through a language

3 Which is why, using Bing Translate, I can confidently write (and much less confidently say) "pongwIj 'oH Anca" in Klingon. 
that intentionally resembles nothing familiar, as is the case of Elvish or Klingon, that have their own cultural backgrounds that were created either before or after the invention of the language per se:

While one might think that these languages were created to give his stories more realism, it was actually the reverse that occurred: Tolkien developed his languages first, and then to give them context, he established a detailed historical background from which his stories emerged. (Incidentally, culture is not neglected in the study of either Klingon or elvish. Compare, for instance, the Klingon greeting «nuqneH» (literally, «what do you want?») with a typical Quenya Elven greeting «Elen síla lúmenn' omentielvo» (literally, «a star shines on the hour of our meeting») (Koenig).

b) or to reflect a system of thought, namely the fictional languages with semi-unique occurrences, that may or may not need to be translated, as is the case of the Leopard language created by Virgil Teodorescu, for instance.

One of the most interesting manifestations of a fictional language can (once again) be found in the Star Trek universe, namely the language of the Children of Tama (Star Trek: The Next Generation, Season 5, Episode 2: "Darmok", September 30 ${ }^{\text {th }} 1991$ ), which is one of the few occurrences that combines the functionality of a new language (thus reflecting the intention of differentiating that particular species from the one with which we identify) and a literarity pushed to the extreme, which almost harms the communication: the Tamarian language is formed exclusively of allegorical structures. "Darmok and Jalad at Tanagra", for example, can be translated to "let's work together" and it is a direct reference to a moment in the history (or the mythology) of the Tamarian people in which the protagonists (Darmok and Jalad) collaborated. The language is built entirely based on the cultural background. Ian Bogost published in The Atlantic a very detailed analysis of the Tamarian language:

Allegory might have been a better term for explaining Tamarian. While metaphor represents one subject as similar to another object, allegory replaces one with another entirely. Allegory's veiled language is powerful, because allegories effectively freeze time, making a historical or fictional scenario immortal. Allegory is what makes it possible for 
us to continue to derive lessons from the Old and New Testaments, week after week, homily after homily (...) But the Tamarians' version of allegory, if that's indeed the right name for it, cuts both ways. On the one hand, it fetishizes myth in the manner of allegory, but on the other hand it musters that myth in the interest of serious sociopolitical action, as evidenced by Dathon's willingness literally to die in the name of myth. So [Walter] Benjamin's concerns about the abandonment of the present don't seem to apply to the Tamarian situation, offering further doubt that allegory is the best way to describe their communication process (Bogost).

Although, essentially, Tamarian seems to be rather a new (complicated) form of communication (a cumbersome one, impossible even, for someone who had not familiarised himself with the entire culture of the Tamarian people beforehand), it is nonetheless a new language, without having invented new words.

If we pretend that «Shaka, when the walls fell» is a signifier, then its signified is not the fictional mythological character Shaka, nor the myth that contains whatever calamity caused the walls to fall, but the logic by which the situation itself came about. Tamarian language isn't really language at all, but machinery (Bogost).

Behind the names of the mythological or historical figures lie features, active or passive actions, so adjectives, verbs, adverbs etc., all gathered under a proper name. The exclusively allegorical communication is, in the case of the Children of Tama, the condensed version of a fictional language.

In other words, were we to apply the same system to the Romanian people, we would use structures such as "Vlad the Impaler and Mehmed II in Târgoviște" and the interlocutor would immediately know that the reference points to the Night Attack from 1462 and they would be able to deduce all necessary nouns, adjectives, verbs, adverbs and such, in order to understand that what I just said is something on the lines of "let's be sneaky and then really aggressive" (or even, depending on which side each speaker is on: "I will surprise attack you" or "I am confused and violent"). 


\section{Atoning for educability through delicate beauty}

The issue of untranslatability implies the existence of a linguistic code and a set of rules. The semantic transfer thus implies a cultural negotiation of meaning between the two languages. In the absence of the code and in the absence of the rules, the cultural negotiation of meaning no longer takes place, considering the fact that the meaning resides somewhere else entirely. The invented/fictional languages of the Romanian literary Avant-Garde could thus be not necessarily artificial languages, but autonomous forms of meaning. Of course, depending on the context and on the stance taken by a reader, the word „autonomous” could easily be replaced by „anarchist” or „chaotic”, given the apparent non-compliance with the conventional, but their empowerment through this non-compliance rather leads to an approach based on the inner strength of their purposes. "Artificial" can also be replaced with "secret", which opens up entirely different interpretation paths. Childhood secret languages, for instance, are considered to be anti-languages, which takes the discussion back to the original issue of purpose: to hide or to reveal?

The concept of untranslatable may conceptually come into contact with the idea of the unspeakable, in the sense of something that cannot be uttered, which is dangerously close to silence, when, in fact, fictional languages are loud, through the strength and noise made by their use as epitomes of certain theoretical stances.

An entirely new language that appeals to no previously established cultural sphere would solve many of the issues raised by the Avant-Garde manifestoes. Ilarie Voronca, for instance, in Grammar approaches the problem of meaning and translatability in the sense that

the same terms in different languages constantly change. For many drum, chemin, weg, cammino mean the same thing. Which is inexact. Chemin is completely different from drum or cammino, since the road here is completely different than the road in Italy, which in its turn is completely different from the road in France. Above the style and the meaning of each expression lies the style and the meaning of the times and the regions. Each word itself means, above its meaning, the sensibility and the sonority if the epoch. This is why I stated that words are untranslatable and a poem in which the first verse is fumatul e interzis (smoking is forbidden) and the second is rauchen verboten is not a 
repetition, but two completely different verses. The response to the untranslatability of words is the translatability of gibberish ${ }^{4}$ (Voronca 37 ).

Voronca, pleading for the translation of the "oddities" and the "gibberish" from one language into another (or from a "language" into a language), concludes with the now more than famous recommendation: "Make grammatical mistakes!". In this sense, an artificial language is also the response to the incentive present in $75 \mathrm{HP}$ in big red letters "INVENT INVENT INVENT".

The essence of a fictional language implies the idea of inflicting violence on language itself. However, a new "code", in order to remain relevant, must be accepted by the group, which diminishes its violence. Robert Escarpit considers that, on a linguistic level, the writer can only use the vocabulary and the syntax used by his community and, at most, he could only give a purer meaning to the words of the tribe, words that will continue to belong to the tribe and that cannot be extracted with no damage (Escarpit 90). If the "PERMANENT EFFORT FOR THE LIBERATION OF HUMAN EXPRESSION IN ALL ITS FORMS”5 (Naum, Păun, Teodorescu, 291) leads, among other things, to the detonation of semantics and semiotics as a form of liberation, the "words of the tribe" are either in a permanent evolution, or in a permanent movement against the norm. Wolfgang Iser raises the issue of the function of the "anti", as a deviation from the norm, in the sense that the violation of the standard possesses a poetic quality as long as the violated standard is also present and cited (Iser 209-211).

In the Avant-Gardes, violence is inflicted upon the text in different forms, but the translation of the untranslatable must be one. By creating a new language, the traditional linguistic norms are violated, creating a linguistic or cultural blockage and, by translating the new language, the text resulted through the semantic transfer is

\footnotetext{
4 "Există, pentru noi, o savoare aproape senzuală a înlănțuirii, în ciuda sensului, a cuvintelor. Aceleași noțiuni în diferite limbi se schimbă mereu. Pentru mulți: drum, chemin, weg, cammino înseamnă același lucru. Inexact. Chemin e cu totul altceva decât drum sau cammino, pentru că drumul de la noi e cu totul altfel decât drumul din Italia, şi acesta altfel decât cel din Franța. Mai presus de stilul şi noțiunea fiecărei expresii, este stilul și noțiunea unei epoci sau a unui ținut. Fiecare cuvânt în sine înseamnă, mai prețios decât înțelesul lui, sensibilitatea și sonoritatea epocei. De aceea spunem că sunt intraductibile cuvintele şi de aceea o poezie în care versul întâi ar fi: fumatul e interzis și al doilea rauchen verboten, nu înseamnă o repetiție, ci două versuri perfect distincte. La intraductibilitatea cuvintelor răspunde însă intraductibilitatea idiotismelor", (my translation).

5 “PERMANENTUL EFORT PENTRU ELIBERAREA EXPRESIEI UMANE SUB TOATE FORMELE EI", (my translation).
} 
violated, since it does not appeal to any original cultural sphere and the negotiation of meaning with the source cultural context does not take place. On this note, the act of translation itself (not only in the case of a fictional language) has been somewhat linked to an act of treason - as G. Rabassa puts it, beginning from "the Italian punning canard traduttore, traditore (translator, traitor)" (Rabassa 3), translation is linked to a form of betrayal, manifested in all directions, from the betrayal of the language, to the betrayal of the words themselves, to "personal betrayals, those against the people involved in the act of translation. The first victim is, of course, the author we are translating. Can we ever make a different-coloured clone of what he (read he $\backslash$ she, as in a U.N. document) has done?" (4). It would thus appear that no matter which (type of) language is translated, the translator and the act of translation cannot catch a break. Its strong ties to more or less intense forms of violence (betrayal is, after all, far from being a good thing) turn it into a process that may raise more ethical questions than one could have anticipated. G. Rabassa asserts that different languages are somewhat similar to one another just like the colours on a spectrum (taking the example of Columbia's blue vs. Yale's blue), but he also states that there are colours that are invisible to us, somewhere at the ends of the spectrum: "The limits of our ability to perceive show up in the fact that we are unable even to imagine what these colours might be like. We would have to be certain birds" (21); or, I would add, we could just be Klingons, or Elves, or... leopards, even?

A new language creates a fertile and germinating cultural blockage. Its translation demolishes the blockage that could have been approached as a stand-alone entity. The fictional language is the untranslatable that carries and reflects the "deconstruction of the natural language" and it has a life of its own. The "leopard language", for instance, has been said to "live exclusively through its translations" (Gulea 291). However, if we are to understand it as the embodiment of surrealist theory, in two versions (fictional and translated), it bears more meaning than simply more or less infantile and playful experiments. The translations provided by the authors (as is the case of Virgil Teodorescu's Poem in the Leopard Language, in which Sobroe algoa dooy toe founod also appears as In a few days you'll find your shadow) can be interpreted as either the final analogy of function or as half of what constitutes a dual form of reflecting a theoretical stance: the musical version of theory. 
Untranslatability may not necessarily be present only in fictional languages. Phonetic poems function in a similar fashion and they are not necessarily the results of creative exercises, but reflectors of theoretical inventions. Untranslatability is the carrier, for instance, for the non-oedipal thought in the poetic occurrences of Gherasim Luca's "prodigious stutters" (as in "Never enough") ${ }^{6}$, in which the language is a deconstruction, transmutation and repetition of the syllables present in the title, resulting in a structure that is "the essence of style". On this issue Deleuze stated that

a style is managing to stammer in one's own language. It is difficult, because there has to be a need for such stammering. Not being a stammerer in one's speech, but being a stammerer of language itself. Being like a foreigner in one's own language. Constructing a line of flight. The most striking examples for me are Kafka, Beckett, Gherasim Luca and Godard. Gherasim Luca is a great poet among the greatest: he invented a prodigious stammering, his own. He gave public readings of his poems in front of two hundred people; and yet it was an event, an event belonging to no school or movement, which pass through these two hundred (Deleuze, Parnet, 4).

A fictional language as an anti-language reflects just that: the permanent negation and the negation of the negation. The complete liberation of human expression from all its forms, as militantly and repeatedly stated (in one form or another) in the manifestos (present in this exact form in Gelu Naum, Paul Paun and Virgil Teodorescu's Critique of Misery). Or, in the case of Geo Bogza's Incantation ("Hau! Hau! Hau! / rota dria vau”), for instance, a reflection of the primal (purest?) form of expression in a folk or mystical shape.

Ovidiu Morar transposes the Avant-Garde linguistic inventions (not merely the invented languages per se, but also their phonetic poems) into certain forms of manifesting a political refuge in their own historical context:

The same refusal of root-striking urged them, even when living in Romania, to write in French, the international language of the avant-garde, or to exile themselves in their own

\footnotetext{
${ }^{6}$ For a more in-depth approach on this issue, see Ovidiu Morar, "The Non-Oedipal Thought of Gherasim Luca", in Philologica Jassynesia (2014), Vol. 10, Issue 2:

http://www.diacronia.ro/ro/indexing/details/A14967/pdf (accessed in December 2019).
} 
language, decomposing and recomposing it ad libitum in order to create an autonomous poetic language, genuinely international (...). Naturally, the cosmopolitan bet aims also at the proper creation of the avantgarde, both on the thematic and on the formal level. The first thing one may notice is its eminently anti-national character, in the sense that, thematically, it does not refer to an autochthonous nature, to a «spirit of the nation», to a specific paideuma, or to other «roots» of Romanianness. In other words, Romanian avant-garde art is not Romanian, as it refuses the rooting in the «national specific» obstinately searched by the traditionalists. And if the old traditional themes do appear, it is only that they should be amended (Morar, 243-244).

Certain critical approaches deemed the fictional languages of the Romanian AvantGarde to be forms of anti-nationalism, somewhat camouflaged in the colours of cosmopolitism. Cosmopolitism, or translingualism, does indeed appear to be the manifestation of a political choice, or a political stance, particularly from the perspective of the cultural charge of any language. The choice of using one language or another is truly (also) a political one.

Translinguals are the shock troops of modern literature, and those avant-garde movements that, like Dadaism, Surrealism, and Futurism, have been most insistent on the inadequacy and treachery of conventional speech, have been led by multilinguals, translinguals, and other cosmopolitans. (...) Translinguals also often remind us of the political implications of language, of the role that it plays in defining a community. In multilingual societies like Belgium, Canada, Finland, India, Switzerland, or Yugoslavia, the choice of a literary medium is not an innocent act. (...) Language implicates its user in the values and visions of a culture. Multilingualism implicates and extricates (Kellman 538-539).

Emily Apter identified the forms of untranslatability as fruitful failures: "I would activate the Untranslatable, not as pure difference (rightly suspect as just another form of the romantic Absolute, or fetish of the Other, or myth of hermeneutic inaccessibility), but as a linguistic form of creative failure with homeopathic uses" (Apter 178). Thus, the idea of the translation failure 
invites elaboration alongside other iterations of the non-translatable: ale theia (hidden being, truth), glossolalia or speaking in tongues, gnomic utterances, technical jargons, the nonpareil, anagrammatic cipher, das Unversta"ndlich (the un-understandable), as well as Wittgenstein's notions of das Unaussprechlichen, (the inexpressible), das Unsagbare (the unsayable, the unspeakable), as in the famous proposition from the Tractatus: «Whereof one cannot speak, thereof one must be silent»), and use of the term sinnlos to refer to nonsense (178).

In the present case, however, the "nonsense" is much more than playful gibberish, since its function is to reflect credos clearly stated in manifestoes. The existence of fictional languages checks the boxes left empty by the literary works constructed in more "traditional" manners: they are unique creations that resemble nothing of the familiar enshrined past and they employ the audio and visual senses in order to construct meaning (while Teodorescu's Leopard language is almost entirely visual and almost impossible to read out loud, Bogza's Incantation or even Nina Cassian's Sparga language are audible creations). As such, the term "translation" may not be completely appropriate in the case of fictional languages that only play aesthetic roles. David Bellos came up with a series of alternatives that may actually come in handy were one to make such an attempt: “«Turning», «transmitting», «speaking after», «mouthing» and «exchanging»" (Bellos 30), since, in all fairness, the concept of "translation" has always been linked to a singular metaphor that may actually not apply in all situations, that of a "carrier of meaning" over certain "barriers":

Would we have ever thought up the idea of a «language barrier» if our word for translator did not imply something like «truck driver»? Would we have ever asked what a translator «carries across» the «language barrier» if he or she we called a «turner», «tongue-man», or «exhanger»? (30).

Thus, since the aforementioned "educability" is almost completely out of the question in the case of the fictional languages of the Avant-Garde, perhaps a more fruitful term for their "traditional language" versions could actually be "mouthings", or "tongue-texts". 


\section{References:}

Apter, E., "Philosophizing World Literature", Contemporary French and Francophone Studies, Vol. 16, No. 2, March 2012.

Bellos, D., Is That a Fish in Your Ear? Translation and the Meaning of Everything, Penguin Books Limited, 2011.

Bogost, I., "Shaka, When the Walls Fell. In one fascinating episode, Star Trek: The Next Generation traced the limits of human communication as we know it-and suggested a new, truer way of talking about the universe", The Atlantic, June 18, 2014: https://www.theatlantic.com/entertainment/archive/2014/o6/star-trektng-and-the-limits-of-language-shaka-when-the-walls-fell/372107/ (accessed April 2020).

Concise Oxford Companion to the English Language: https://www.encyclopedia.com/humanities/encyclopedias-almanacs-transcriptsand-maps/stunt-word (accessed March 2020).

Cornea, P., Interpretare și raționalitate. Polirom, 2006.

Deleuze, G., C. Parnet, Dialogues II, Columbia University Press, 2007.

Eaton, H. S., "The Educational Value of an Artificial Language”, The Modern Language Journal, Vol. 12, No. 2 (Nov., 1927), available full-text in JSTOR.

Escarpit, R., De la sociologia lecturii la teoria comunicării: studii şi eseuri, transl. by Sanda Chiose Crișan. Editura Științifică şi Enciclopedică, 1980.

Frențiu, R., "Literary Translation as a Hermeneutic and Poetic Dialogue in the Cultural Semiosphere”, RIELMA. Revue Internationale D'Études en Langues Modernes Appliquees, Supplément au numéro 11 / 2018, p. 50: https://lett.ubbcluj.ro/rielma/RIELMA_no11_2018_Supplement.pdf (accessed in April 2020).

Gulea, D., Marginaliile avangardelor. Tracus Arte, 2016.

Iser, W., Actul lecturii: o teorie a efectului estetic, transl. and pref. by Romanița Constantinescu. Editura Paralela 45, 2006.

Kellman, S. G., "Translingualism and the Literary Imagination", Criticism, Wayne State University Press, Vol. 33, No. 4 (fall, 1991), available full-text in JSTOR. 
Koenig, J., "Constructed Languages - Linguistics as an Art Form": https://www.russtechinc.com/blog/constructed_languages_linguistics_as_an_ar $\mathrm{t} \_$form (accessed in March 2020).

Lezra, J., "This untranslatability which is not one”, Paragraph, Volume 38, Issue 2, July 2015 (DOI: 10.3366/para.2015.0156).

Lotman, I. M., Cultură și explozie, transl. by George Ghețu and Justina Bandol, pref. Livia Cotorcea, Editura Paralela 45, 2004.

Morar, O., "The Cosmopolitism of the Romanian Avant-Garde", in Philologica Jassyensia (2013), Vol. 9, Issue 2.

Okrent, A., In the Land of Invented Languages. Esperanto Rock Stars, Klingon Poets, Loglan Lovers, and the Mad Dreamers Who Tried to Build A Perfect Language, Random House Publishing Group, May 19, 2009.

Rabassa, G., If This Be Treason. Translation and Its Dyscontents. A memoir. New Directions Books, 2005.

"Supercalifragilistic" in Urban

Dictionary: https://www.urbandictionary.com/define.php?term=supercalifragilisticexpialidoc ious (accessed March 2020).

Tătaru, C., "On metaphor and the problem of untranslatability", in Constructions of Identity (II), ed. Adrian Radu, Editura Napoca Star, 2004.

"The Real Origin of 'Supercalifragilistic'”, Merriam-Webster: https://www.merriamwebster.com/words-at-play/origin-supercalifragilisticexpialidocious (accessed March 2020).

Trahair, R.C.S., Utopias and Utopians: An Historical Dictionary of Attempts to Make the World a Better Place and Those Who Were Involved, Routledge, Oct 31, 2013, entry: Esperanto.

Voronca, I., "Gramatică”, in Ion Pop, Avangarda românească. Editura Fundaţia Naţională pentru Ştiinţă şi Artă, 2015. 